\title{
Open Science to Knowledge without Borders
}

\author{
Elizabeth da Costa Mattos ${ }^{1, *}$ (D) \\ 1.Departamento de Ciência e Tecnologia Aeroespacial - Instituto de Aeronáutica e Espaço Divisão de Propulsão São José dos \\ Campos/SP, Brazil \\ *Correspondence author: editor@jatm.com.br
}

Open science encompasses several actions that impact on scientific activities. We can say that open science is the result of other movements, dating from the end of the last century, such as Open Archives and Open Access, resulting from the technological evolution and crisis of the journals respectively. Open science is incorporating existing precepts and proposing new challenges to the world scientific community (Shintaku and Lanne 2020)

Rodrigues et al. (2019) mentions in an article that, since 2002, the Movement of Free Open Access to Scientific Information was already known and has been expanding its dimensions over time. The researchers obtained as a result of their research that open access was very well accepted and that there was a consensus among researchers to preserve, value and share scientific publications.

Open Science is a renewed way of producing, disseminating and using scientific knowledge (Albagli 2015). It refers to the availability and opening of data, so that they are available for dissemination, with free and unpaid access, with greater transparency in scientific methods and so that they will be reused and better used by all researchers and by society (FAPEG 2019).

Open Science presents itself as an umbrella, encompassing several initiatives that impact not only the dissemination of results in articles, as in the case of scientific publishing, but also initiatives that concern intermediary research activities, such as research notebooks or negative results. So that the study data are more transparent, available and reproducible, contributing to a more reliable science. In addition, it seeks to establish the technological infrastructure and incentives for this to happen (Sales et al. 2020)

Considering that knowledge is a good that must be shared, the use of open science must be encouraged and applied by the entire scientific community, such as universities, development agencies, publishers and government agencies (Martins 2020).

According to Abadal (2019), "Open science is a way of conceiving scientific research that is based on collaborative work, on the openness and transparency of all phases of research (data collection, expert review, dissemination, evaluation, etc.) and also on the approach of science to society". Open science supposes a radical transformation in the way scientific research is carried out and how to transform its evaluation system, in short, a whole paradigm shift in relation to the current system.

Brazil is committed to Open Science within the National Open Government Action Plan. The main organizations that support science in Brazil, both the CAPES (Coordenação de Aperfeiçoamento de Pessoal de Nivel Superior) and the CNPq (Conselho Nacional de Desenvolvimento Cientifico e Tecnológico) participate in this national action plan with the objective of advancing Open Science in Brazil, which reinforces the view that, in the short term, it will be widely disseminated in the country.

Brazil has led the open access movement since 2003 and currently has 924 open access journals listed in the Directory of Open Access Journals (DOAJ), being the second country in terms of Open Access Journals (Springer 2020).

In the event of the SciELO Week 20 years, the state of the art of scientific communication was discussed, which is going through one of the greatest periods of transformation, with the emergence of open science (Packer et al. 2018). SciELO (Scientific Electronic Library Online) is an electronic library that covers a selected collection of Brazilian scientific journals. In this context, one of the most difficult transformations in the communication ecosystem of international research is the universalization of open access to scientific literature, a goal that was adopted 20 years ago by the SciELO project, which has placed Brazil and other SciELO Network countries as pioneers of the Open Access movement (Packer et al. 2018).

Received: Jan. 06, 2021 | Accepted: Jan. 18, 2021

Section Editor: Invited author, no peer review.

Peer Review History: Ana Morais

This is an open access article distributed under the terms of the Creative Commons license. 
However, Open Science extends the demand for open access to beyond the articles, and encompasses all dimensions of research, which makes the insertion of journals highly challenging as it requires, along with other instances, to advance a renewed approach to functions, policies and operation of journals (Packer et al. 2018).

SciELO journals and their research communities see the concept of openness as an inherent practice of communicating research results, which will favor the transition to open science (Packer et al. 2018).

The CNPq proposed the expansion of the Lattes Platform (virtual curriculum system created and maintained by CNPq, by which it integrates the curricular databases, research groups and institutions into a single information system, in the areas of Science and Technology, operating in Brazil ) creating the Lattes Data. The purpose of Lattes Data is to have a repository for storing scientific data, constituting one of the dimensions necessary for the implementation of Open Science in Brazil in order to provide access to knowledge, resulting from scientific research financed with public resources from the CNPq (FAPEG 2019).

In addition, the materialization of Open Science in Lattes Data, can both catalyze scientific research by promoting increased efficiency in the production of science, and enhance the value of the scientific information generated (FAPEG 2019).

The opening of scientific data within the principles of open data undoubtedly has enormous advantages, not only for academics, but for the whole society in general. The information chain would be enriched with a greater diffusion and expansion of the possibilities of uses and reuses of information.

Open Science is based on three strategic pillars: Open Access, Open Data, and Open Peer Review. This peer review system has existed since the appearance of the first magazines. They are usually used by many editors, in double or single blind format, but this model has been widely criticized (Spinak 2018; Oliveira 2018). There is a growing movement among editors, aiming to make the review process public and to start using the open review in which reviewers and authors are identified (Prado et al. 2009).

The Open Peer Review (OPR) process is a recent term that has been understood in open science, as a transparent academic review mechanism, in which the identity of the authors and reviewers is disclosed to each other (Mendes 2019).

Open peer review therefore aims to bring greater transparency and participation to formal and informal peer review processes. Being a reviewer offers researchers the opportunity to get involved with new research, build research networks and specialties, and improve their own writing skills, so using OPR is an advantage (Bezjak et al. 2018).

In this last year, when we are experiencing the advent of the pandemic, the publication of open data has been extremely important, so that information about the new coronavirus can be disseminated very quickly. In this way, the knowledge disseminated brings agility to the development of vaccines and treatment to the world population.

One medium that has been widely used for these publications in order to speed up publications is preprints. They are scientific manuscripts with complete data that are deposited on a public server, before their final publication in a journal (Packer et al. 2017).

The preprint is almost always the same article that will be published, but it has not yet gone through peer review. The preprint is not the finished article, it can be quickly edited several times by the authors and new results can be inserted on the server where the publication was inserted. This allows anyone to access, read and make suggestions and the author can view the number of accesses to his file (Packer et al. 2017).

A great solution for scientific dissemination are preprints, which has been one of the alternatives to overcome the delay in publication, aiming to speed up the dissemination of scientific works.

From October 2020, the JATM, implemented changes related to the worldwide open access movement, such as open peer review and the incentive to publish manuscripts still under evaluation in preprint repositories, with the aim of disseminating immediate research results to the scientific community, as well as referencing research data deposited in repositories. These changes were very well accepted by the authors, and most have opted for an open review.

Since 2019, JATM has been granting credit to the section editor, responsible for managing the peer review including the editorial decision, has adopted the Credit standard for attributing authorship and using Fundref to reference funders.

In this way, JATM fulfills its role, maintaining itself as a reference journal for publishing research results in the area of international aerospace technology, following the modern world trends for publishing its articles. 


\section{REFERENCES}

Abadal E (2019) Ciencia Abierta, un modelo por definir con muchos retos por delante. Hipertext.net, (19), 1-4.https://doi.org/10.31009/ hipertext.net.2019.i19.01

Albagli S (2015) Ciência aberta em questão. In: Albagli S; Maciel ML; Abdo AH (Ed.). Ciência aberta, questões abertas. Brasília: IBICT; Rio de Janeiro: UNIRIO, 2015. p. 9-25

Bezjak S et al. (2018) Edit Görögh, Kerstin Helbig, ... Lambert Heller. Open Science Training Handbook (Version 1.0). Zenodo. http:// doi.org/10.5281/zenodo.1212496

FAPEG (2019). Available at: http://www.fapeg.go.gov.br/cnpq-e-ibict-firmam-acordo-para-implementacao-de-repositorio-de-dadoscientificos. Accessed on: 21 Dec 2020

Machado J (2015) Dados abertos e ciência aberta. In: Albagli, S; Maciel, Albagi S et al. (Ed.). Ciência aberta, questões abertas. Brasília: IBICT; Rio de Janeiro: UNIRIO, 2015. p. 201-219.

Martins HC (2020) A importância da Ciência Aberta (Open Science) na pesquisa em Administração. Rev. Adm. Contemp. Vol.24 No.1 https://doi.org/10.1590/1982-7849rac2020190380

Mendes da Silva W (2019) Revisão pelos Pares Aberta e Ciência Aberta na Comunidade de Pesquisa em Negócios. Revista de Administração Contemporânea, 23(4). https://doi.org/10.1590/1982-7849rac2019190278

Oliveira ECP (2018) Revisão por pares aberta: análise das revistas open access. In: ABEC MEETING, 2018, São Paulo. Anais... São Paulo: Associação Brasileira de Editores Científicos.. https://doi.org/10.21452/abecmeeting.2018.180

Packer AL et al. (2018) SciELO pós 20 Anos: o futuro continua aberto [online]. SciELO em Perspectiva, 2018 [viewed 07 January 2021 ]. Available at: https://blog.scielo.org/blog/2018/12/19/scielo-pos-20-anos-o-futuro-continua-aberto

Packer A L et al. (2017) SciELO Preprints a caminho [online]. SciELO em Perspectiva [viewed 08 January 2021]. Available at: https:// blog.scielo.org/blog/2017/02/22/scielo-preprints-a-caminho/

Prado GF et al. (2009) Editorial. Revista Neurociências, 17(2), 99-100. https://doi.org/10.4181/RNC.2009.17.99

Rodrigues KO et al. (2019) Percepção de pesquisadores de instituições públicas acerca da ciência aberta, Ci.Inf., Brasília, DF, v.48 n.3 (Supl.), p.266-275, set./dez. 2019

Sales L F et al. (2020) Ciência aberta, gestão de dados de pesquisa e novas possibilidades para a editoração científica. In: Shintaku M, Sales L F, Costa M. (org). Tópicos sobre dados abertos para editores científicos. Botucatu, SP: ABEC, p. 13-21. https://doi.org/10.21452/97885-93910-04-3.cap1

Santos GC (2020) Como os indexadores estão vendo a questão de dados abertos de pesquisa para o processo de indexação? In: Shintaku M., Sales L F, Costa M (org). Tópicos sobre dados abertos para editores científicos. Botucatu, SP: ABEC, 2020. p. 97-118. https://doi/ org/10.21452/ 978-85-93910-04-3.cap9

Spinak E (2018) Sobre as vinte e duas definições de revisão por pares aberta... e mais [online]. SciELO em Perspectiva, [viewed 05 January 2021]. Available at: https://blog.scielo.org/blog/2018/02/28/sobre-as-vinte-e-duas-definicoes-de-revisaopor-pares-aberta-e-mais/

Springer (2020) [viewed 08 January 2021]. Available at: https://www.springer.com/societies+\&+publishing+partners/ spotlight+brazil?SGWID=0-1762313-12-1015256-0 